\title{
POLAND'S TRADE WITH EAST ASIA: AN OUTLIER APPROACH
}

Shoiw-Mei Tseng, Assistant Professor

I-Shou University

Department of International Business

No. 1, Sec. 1, Syuecheng Rd., Dashu District, Kaohsiung City 84001, Taiwan

e-mail:wisnia@isu.edu.tw

Received 20 May 2015, Accepted 5 November 2015

\begin{abstract}
Poland achieved an excellent reputation for economic transformation during the recent global recession. The European debt crisis, however, quickly forced the reorientation of Poland's trade outside of the European Union (EU), especially toward the dynamic region of East Asia. This study analyzes time series data from 1999 to 2013 to detect outliers in order to determine the bilateral trade paths between Poland and each East Asian country during the events of Poland's accession to the EU in 2004, the global financial crisis from 2008 to 2009, and the European debt crisis from 2010 to 2013. From the Polish standpoint, the results showed significantly clustering outliers in the above periods and in the general trade paths from dependence through distancing and improvement to the chance of approaching East Asian partners. This study also shows that not only China but also several other countries present an excellent opportunity for boosting bilateral trade, especially with regard to Poland's exports.
\end{abstract}

Keywords: bilateral trade; outlier approach; clustering outliers; Poland; East Asia

JEL classification: C22, F14, O57 


\section{Introduction}

Numerous recent studies in various fields have acknowledged Poland for its excellent achievements in regard to economic transformation, despite the worldwide recession caused by the global financial crisis in 2008. Hunter and Ryan (2011) approved the Balcerowicz Plan, which boosted Poland's economic success. Rae (2013) underlined the pragmatic liberalism that protected Poland from the global financial crisis and enabled it to rise to the status of a successful economy. Duszczyk (2014) affirmed Poland's good economic standing despite the crisis; this was achieved by implementing its own model.

However, the subsequent European debt crisis interrupted Poland's strong economic growth, which had been driven by domestic demand and was heavily dependent on intra-EU trade. ${ }^{1}$ In comparison to the other Visegrad countries, this external trade imbalance has long been Poland's weakness. To achieve sustainable development, Poland has recognized the need to expand the extra-EU trade space, including the dynamic market in East Asia ${ }^{2}$ (EA), where, as Biswas (2013) stated, a new gold rush of future Asia is rapidly taking place. For example, Palonka (2010) emphasized that Poland recently took a diplomatic initiative in actively promoting a trade relationship with China through numerous stimulus packages. Moreover, according to the World Economic Forum, the 2014 enabling trade index (ETI) of the EA region is similar to the EU in average ranking and range of countries, and it is widely superior to the Commonwealth of Independent States (CIS), which has historical ties with Poland (Hanouz, Geiger, Doherty, 2014).

Undeniably, the EA has accounted for a very small share of Poland's imports and exports over the past 10 years, averaging $8.38 \%$ and $2.05 \%$, respectively (Table 1 ). Nevertheless, the dramatic change in trade is the focus of this study. EA had played a vital role in Poland's extraEU trade; however, it was eclipsed by Poland's accession to the EU and the reemergence of the CIS. The EA shared $36.68 \%$ of total extra-EU imports in 1999 , which sharply dropped to $9.04 \%$ in 2013, while exports decreased from $10.23 \%$ to $1.25 \%$ (Table 1). The import/export ratio of Poland to EA decreased considerably from 9.11 in 1999 to 3.31 in 2013, compared with 1.68 to 1.02 worldwide, 1.48 to 0.93 for the EU, and 2.54 to 1.26 for the extra-EU. Poland has gradually strengthened its external competitiveness in the face of globalization, thanks to EU membership and foreign direct investment (FDI) over the past decades (Vintila, 2012; Belka, 2013).

\footnotetext{
1 Intra-EU trade refers to all transactions occurring within the EU, which consists of 27 member states, according to the EuroStat statistics glossary (http://epp.eurostat.ec.europa.eu/statistics_explained/). Conversely, extra-EU trade refers to transactions with the rest of the world, with the exception of the EU.

2 This study defines East Asia as the following 11 East Asian countries: China, Hong Kong, Indonesia, Japan, South Korea, Malaysia, Philippines, Singapore, Taiwan, Thailand, and Vietnam.
} 
Table 1. Composition of Poland's imports and exports with groups of countries from 1999 to $2013(\%)$

\begin{tabular}{|c|c|c|c|c|c|c|c|c|}
\hline \multirow{2}{*}{ Year } & \multicolumn{9}{|c|}{ Of total } & \multicolumn{2}{c|}{ Of Extra-EU } \\
\cline { 2 - 9 } & $\begin{array}{c}\text { EA } \\
\text { import }\end{array}$ & $\begin{array}{c}\text { EA } \\
\text { export }\end{array}$ & $\begin{array}{c}\text { Extra-EU } \\
\text { import }\end{array}$ & $\begin{array}{c}\text { Extra-EU } \\
\text { export }\end{array}$ & $\begin{array}{c}\text { Intra-EU } \\
\text { import }\end{array}$ & $\begin{array}{c}\text { Intra-EU } \\
\text { export }\end{array}$ & $\begin{array}{c}\text { EA } \\
\text { import }\end{array}$ & $\begin{array}{c}\text { EA } \\
\text { export }\end{array}$ \\
\hline 1999 & 10.20 & 1.88 & 27.81 & 18.35 & 72.19 & 81.65 & 36.68 & 10.23 \\
\hline 2000 & 9.39 & 1.75 & 31.05 & 18.79 & 68.95 & 81.21 & 26.64 & 7.46 \\
\hline 2001 & 9.22 & 1.50 & 30.32 & 18.82 & 69.68 & 81.18 & 25.85 & 6.37 \\
\hline 2002 & 9.75 & 1.38 & 30.30 & 18.85 & 69.70 & 81.15 & 24.78 & 5.88 \\
\hline 2003 & 9.96 & 1.37 & 30.39 & 18.08 & 69.61 & 81.92 & 23.94 & 5.61 \\
\hline 2004 & 6.94 & 1.68 & 24.67 & 19.67 & 75.33 & 80.33 & 24.68 & 4.06 \\
\hline 2005 & 6.36 & 1.55 & 24.67 & 21.38 & 75.33 & 78.62 & 21.79 & 3.14 \\
\hline 2006 & 7.19 & 1.67 & 27.00 & 21.03 & 73.00 & 78.97 & 16.08 & 2.60 \\
\hline 2007 & 7.97 & 1.66 & 26.71 & 21.12 & 73.29 & 78.88 & 13.60 & 2.23 \\
\hline 2008 & 8.39 & 1.66 & 28.15 & 22.19 & 71.85 & 77.81 & 10.99 & 1.87 \\
\hline 2009 & 9.96 & 2.18 & 27.44 & 20.38 & 72.56 & 79.62 & 14.93 & 2.42 \\
\hline 2010 & 9.87 & 2.31 & 29.22 & 20.89 & 70.78 & 79.11 & 11.19 & 1.91 \\
\hline 2011 & 8.82 & 2.43 & 30.46 & 22.18 & 70.95 & 78.51 & 9.66 & 1.61 \\
\hline 2012 & 9.13 & 2.58 & 32.82 & 24.27 & 67.18 & 75.73 & 8.77 & 1.39 \\
\hline 2013 & 9.21 & 2.82 & 31.47 & 25.42 & 68.53 & 74.58 & 9.04 & 1.25 \\
\hline
\end{tabular}

Source: Eurostat.

From another viewpoint, after Poland's accession to the EU, exports to EA increased rapidly, averaging $21.45 \%$ annually from 2004 to 2013 and even a positive $10.98 \%$ in the globally dark year of 2009 (Table 2). The imports decreased by 16.7\% in 2004 but grew by an average of $16.4 \%$ from 2005 to 2013 , with the exception of a negative $10.32 \%$ in 2009 . Indeed, EA's share of imports quickly fell to 6.94\% in 2004 from $9.96 \%$ in 2003 because of Poland's membership in the EU, while the EU share rose to $75.33 \%$ from $69.61 \%$. Nevertheless, since the EU depression in 2009, it has reached the previous level of 9\%, as shown in Table 1.

This study, therefore, aims to explore Poland's trade with the EA region and individual countries within it. In this study, from the standpoint of Poland, the trade paths of EA imports and exports are interpreted based on the analysis of time series data to detect the differences among the countries. However, research that attempts international comparisons is challenged by the erratic fluctuation of trade volumes and the very small body of literature on this issue. Bilateral trade factors are complicated and vary from one country to another not only because of Poland's own economic transformation but also as a result of the high diversity in the EA region (seen in Appendix); as Acharya (2010) pointed out, "Asia is not one.” Accordingly, this study agrees with Nare, Maposa, and Lesaoana's (2012) proposal that an outlier approach is a better way to describe a complex real-world phenomenon when a theory does not work perfectly. 
The outlier often provides insights into the process of trade, which are not available when mean values or linear trends are considered.

Table 2. Growth of Poland's imports and exports by groups of countries from 2000 to $2013(\%)$

\begin{tabular}{|c|c|r|r|r|r|r|r|r|}
\hline Year & $\begin{array}{c}\text { EA } \\
\text { import }\end{array}$ & $\begin{array}{c}\text { EA } \\
\text { export }\end{array}$ & $\begin{array}{c}\text { Extra-EU } \\
\text { import }\end{array}$ & $\begin{array}{c}\text { Extra-EU } \\
\text { export }\end{array}$ & $\begin{array}{c}\text { Intra-EU } \\
\text { import }\end{array}$ & $\begin{array}{c}\text { Intra-EU } \\
\text { export }\end{array}$ & $\begin{array}{c}\text { World } \\
\text { import }\end{array}$ & $\begin{array}{c}\text { World } \\
\text { export }\end{array}$ \\
\hline 2000 & 13.57 & 24.82 & 37.69 & 37.10 & 17.77 & 33.18 & 23.31 & 33.90 \\
\hline 2001 & 3.55 & 0.35 & 3.07 & 17.08 & 6.67 & 16.90 & 5.56 & 16.94 \\
\hline 2002 & 10.46 & -0.73 & 4.30 & 8.42 & 4.39 & 8.18 & 4.36 & 8.22 \\
\hline 2003 & 5.36 & 8.62 & 3.52 & 4.82 & 3.06 & 10.29 & 3.20 & 9.26 \\
\hline 2004 & -16.70 & 55.77 & -3.02 & 38.07 & 29.30 & 24.49 & 19.48 & 26.94 \\
\hline 2005 & 3.76 & 9.82 & 13.31 & 29.51 & 13.29 & 16.62 & 13.30 & 19.16 \\
\hline 2006 & 39.95 & 32.60 & 35.47 & 20.73 & 19.97 & 23.27 & 23.80 & 22.73 \\
\hline 2007 & 32.55 & 14.69 & 18.29 & 16.42 & 20.02 & 15.76 & 19.55 & 15.90 \\
\hline 2008 & 23.54 & 13.61 & 23.71 & 19.05 & 15.12 & 11.80 & 17.41 & 13.33 \\
\hline 2009 & -10.32 & 10.98 & -26.42 & -22.43 & -23.78 & -13.60 & -24.52 & -15.56 \\
\hline 2010 & 24.19 & 30.15 & 33.46 & 26.16 & 22.27 & 22.33 & 25.34 & 23.11 \\
\hline 2011 & -0.78 & 17.52 & 15.80 & 18.65 & 11.34 & 10.89 & 11.08 & 11.74 \\
\hline 2012 & 5.89 & 12.60 & 10.18 & 16.05 & -3.16 & 2.28 & 2.27 & 6.04 \\
\hline 2013 & 2.07 & 16.71 & -2.95 & 11.61 & 3.26 & 4.95 & 1.22 & 6.57 \\
\hline
\end{tabular}

Source: Eurostat.

Instead of using traditional linear models, Balke and Fomby (1994) employed the outlier model to investigate 15 major macroeconomic time series associated with identifiable economic events from 1947 to 1992. Because of the difficulty in interpreting the variable effects of the environment, Farley and Murphy (1997) used the univariate autoregressive integrated moving average (ARIMA) model and outlier detection to propose a strategy to manage the salmon fisheries in Alaska and Northern British Columbia. Yeung and Chiu (2000) applied an outlier analysis to examine the daily Hong Kong stock market index data in 1997 to determine whether the well-known event of the handover of Hong Kong's sovereignty to China affected the stock market. Li and Chan (2005) extended a systematic outlier analysis to cause-specific mortality time series to provide a better understanding of the circumstances.

In summary, this study supposes that Poland's trade with EA countries is not simply dependent on theoretically endogenous factors but is involved in many individual and bilateral conditions that are difficult to model simultaneously. Hence, this study uses unusual observations to track the path of structural changes in bilateral trade. First, the methodology section discusses a time-series model and an outlier approach. Next, the empirical results are fit to the appropriate ARIMA models of each sample country, and then the frequencies of the outliers are analyzed. 
The study concludes by summarizing the findings on Poland's bilateral trade relations with the EA region.

\section{Methodology}

A time series analysis was developed to investigate changes in a given economic variable over time. Much of the literature has been devoted to time series analysis either to better understand the data or to forecast patterns of seasonality, trends, and cycles. This study focuses on the monthly data on bilateral trade between Poland and the 11 EA partners (Table 3) in the 15 years between 1999 and 2013. The successive data on import (i) and export (e) variables were taken from Easy Comext of Eurostat, and 22 monthly series, with 180 observations each, were selected.

Table 3. Codes of sample countries.

\begin{tabular}{|l|c|c|c|}
\hline \multicolumn{1}{|c|}{ Country name } & Country code & Import code & Export code \\
\hline China & $\mathrm{CN}$ & $\mathrm{CN} i$ & $\mathrm{CN} e$ \\
\hline Hong Kong & $\mathrm{HK}$ & $\mathrm{HK} i$ & $\mathrm{HK} e$ \\
\hline Indonesia & $\mathrm{ID}$ & $\mathrm{ID} i$ & $\mathrm{ID} e$ \\
\hline Japan & $\mathrm{JP}$ & $\mathrm{JP} i$ & $\mathrm{JP} e$ \\
\hline South Korea & $\mathrm{KR}$ & $\mathrm{KR} i$ & $\mathrm{KR} e$ \\
\hline Malaysia & $\mathrm{MY}$ & $\mathrm{MY} i$ & $\mathrm{MY} e$ \\
\hline Philippines & $\mathrm{PH}$ & $\mathrm{PH} i$ & $\mathrm{PH} e$ \\
\hline Singapore & $\mathrm{SG}$ & $\mathrm{SG} i$ & $\mathrm{SG} e$ \\
\hline Taiwan & $\mathrm{TW}$ & $\mathrm{TW} i$ & $\mathrm{TW} e$ \\
\hline Thailand & $\mathrm{TH}$ & $\mathrm{TH} i$ & $\mathrm{TH} e$ \\
\hline Vietnam & $\mathrm{VN}$ & $\mathrm{VN} i$ & $\mathrm{VN} e$ \\
\hline
\end{tabular}

Source: own work.

Time series observations are usually influenced by interruptive events, such as economic crises, changes in policy regimes, natural disasters, or wars. Such observations are generally considered outliers, which researchers have investigated for centuries. According to Grubbs (1969), "an outlying observation, or outlier, is one that appears to deviate markedly from other members of the sample in which it occurs." Barnett and Lewis (1994) noted that it is "an observation (or subset of observations) which appears to be inconsistent with the remainder of that set of data." Hawkins (1980) explained that "an outlier is an observation that deviates so much from other observations as to arouse suspicion that it was generated by a different mechanism." 
In this study, the detection of outliers is based on a univariate time series model. First, this study refers to the common Box-Jenkins ARIMA methodology to model the observed data in each series. An ARIMA model with both seasonal and nonseasonal factors is defined as ARIMA $(p, d, q)(P, D, Q) s$, where $p$ and $P$ are the orders of autoregression; $d$ and $D$ are the orders of differencing; $q$ and $\mathrm{Q}$ are the orders of the moving-average process; and $s$ equals 12 for the monthly series.

Assume that the general $\operatorname{ARIMA}(p, d, q)$ model is the following:

$$
D(B) Y_{t}=\mu_{t}+\frac{\theta(B)}{\phi(B)} a_{t}
$$

where $Y_{t}$ is the response series at time $t ; D(B)$ is the differencing polynomial in the backward shift operator $B ; \eta_{t}$ is the transfer function input; $\phi(B)$ and $\theta(B)$ are the AR and MA polynomials, with orders $p$ and $q$, respectively; and $a_{t}$ is the Gaussian white noise series.

To identify ARIMA models effectively and accurately according to the same criteria, 864 ARIMA $(p, d, q)(P, D, Q)_{12}$ models were selected for each series to automatically determine the best one. This was done using SAS/ETS software, where $p=0,1, \ldots, 5 ; d=0,1,2 ; q=0,1$, ..., $5 ; P=0,1 ; D=0,1 ; Q=0,1$. The diagnostic criteria of adequate models are as follows: All the parameter estimates are significant, and the residual series is white noise. If no models are available, the log transformation is used to convert the given time series. Among the adequate models in a given series, the optimum model is according to the minimum Akaike information criterion (AIC).

The fitted ARIMA model is then incorporated to detect outliers by testing a shock signature $\left(\eta_{t}\right)$ at time $t$, according to SAS automatic outlier detection (SAS, 2002), $H_{0}: \beta=0$ versus $H_{1}: \beta \neq 0$ in the model:

$$
D(B)\left(Y_{t}-\beta \eta_{t}\right)=\mu_{t}+\frac{\theta(B)}{\phi(B)} a_{t}
$$

where $\eta_{t}$ is a regression variable describing some type of change in the mean response. This study considers that the types of outliers are additive outliers (AO), level shifts (LS), and temporary changes in 12 months (T12), according to Tsay (1988).

An AO at some time point $s$ corresponds to a shock signature $\eta_{t}$ such that $\eta_{s}=1$ and $\eta_{t}=0$ at all other points. Similarly, LS has a shock signature at time $s$ such that $\eta_{t}$ is 0 for $t<s$ and 1 for $t \geq s$. A T12 of duration $d$ (12 months) at time $s$ has $\eta_{t}$ equal to 1 between $s$ and $s+d$ and 0 otherwise. This study detects outliers by using a maximum-likelihood estimate and a significance criterion of $1 \%$. To reveal any outlier completely, there is no limit to the 
number of outliers to be searched. More importantly, the estimation of outliers can cause either a positive or a negative effect.

An AO views a sudden break that affects a time series at one period only. LS allows a gradual change that permanently affects the subsequent level of a series. A T12 is a spike that takes a few periods to disappear exponentially and may be a generalization of AO or LS in that it causes an initial effect, such as an AO or LS, which is abbreviated to AOT12 and LST12 in this study. In most cases, the AO presents the relative frequency to the other type of outliers in a given series.

It is noteworthy that this outlier analysis adjusts the volumes of Poland's exports to China, excluding the 74 th chapter of copper products, which accounted for $24 \%$ to $47 \%$ of the total over the past 15 years and were mostly traded by a single company - KGHM Polska Miedź SA (Michalski, 2010). This bias largely affected the monthly time series and might have obscured the whole view of the model, which was not seen in the other countries included in this study. In addition, because of the wide range of the trade values of each country, the outlier analysis of the EA region used the sum of the outlier results in the individual countries.

In this study, outlier frequency is used to compare within series over a given period, especially those corresponding to the events of Poland's accession to the EU in 2004, the global financial crisis in 2008 and 2009, and the European debt crisis from 2010 to 2013. When such events occur, the clustering of outliers must be attended to within series, which in this study is called "clustering outliers." This study supposes that the greater the frequency of outliers in a time series, compared with other time series or other given periods, the greater the sensitivity to interruptive events, or the more that opportunities or threats in bilateral trades depended on the positive/negative effects and types of outliers. Conversely, fewer outliers could represent a robust increase, decrease, or static effect on trade, corresponding to the value trend in a given period. Briefly, this macro outlier approach highlights differences within the imports and exports of countries and periods by frequencies, positive and negative effects, and types of outliers.

\section{Empirical Results}

\subsection{Fitted ARIMA models}

The fitted ARIMA models were adequate and relevant, as reported in Table 4, according to minimum AIC. The log-transformed ARIMAs appear as TW $i$, IDe and JPe. In addition, all models were seasonal because the time series of international trade generally exhibit cyclical variations. 
Table 4. Fitted ARIMA models

\begin{tabular}{|c|c|c|c|}
\hline Code & Import ARIMA model & Code & Export ARIMA model \\
\hline $\mathrm{CN} i$ & $\operatorname{ARIMA}(3,1,1)(0,1,1)_{12}$ & $\mathrm{CN} e$ & $\operatorname{ARIMA}(1,2,2)(0,1,1)_{12}$ \\
\hline $\mathrm{HK} i$ & ARIMA $(4,0,4)(1,1,1)_{12}$ & $\mathrm{HK} e$ & $\operatorname{ARIMA}(2,2,2)(0,1,1)_{12}$ \\
\hline $\mathrm{ID} i$ & $\operatorname{ARIMA}(0,1,1)(0,1,1)_{12}$ & $\mathrm{ID} e$ & $\log \operatorname{ARIMA}(1,1,1)(0,0,1)_{12}$ \\
\hline $\mathrm{JP} i$ & $\operatorname{ARIMA}(1,2,2)(0,1,1)_{12}$ & $\mathrm{JPe}$ & $\operatorname{LogARIMA}(4,1,1)(1,0,1)_{12}$ \\
\hline $\mathrm{KR} i$ & $\operatorname{ARIMA}(5,1,1)(0,1,1)_{12}$ & $\mathrm{KRe}$ & $\operatorname{ARIMA}(5,2,2)(0,1,0)_{12}$ \\
\hline MY $i$ & $\operatorname{ARIMA}(2,2,2)(0,1,1)_{12}$ & MYe & $\operatorname{ARIMA}(5,2,2)(1,1,1)_{12}$ \\
\hline $\mathrm{PH} i$ & $\operatorname{ARIMA}(1,2,2)(0,1,1)_{12}$ & $\mathrm{PHe}$ & $\operatorname{ARIMA}(3,2,2)(0,1,1)_{12}$ \\
\hline $\mathrm{SG} i$ & $\operatorname{ARIMA}(1,2,2)(0,1,1)_{12}$ & $\mathrm{SG} e$ & $\operatorname{ARIMA}(1,2,2)(1,1,1)_{12}$ \\
\hline $\mathrm{TH} i$ & $\operatorname{ARIMA}(3,1,1)(0,1,1)_{12}$ & $\mathrm{TH} e$ & $\operatorname{ARIMA}(3,2,2)(0,1,1)_{12}$ \\
\hline TW $i$ & $\operatorname{LogARIMA}(1,1,3)(1,1,1)_{12}$ & TWe & $\operatorname{ARIMA}(5,2,2)(1,1,1)_{12}$ \\
\hline $\mathrm{VN} i$ & $\operatorname{ARIMA}(4,2,1)(0,1,1)_{12}$ & $\mathrm{VNe}$ & $\operatorname{ARIMA}(1,2,2)(0,1,1)_{12}$ \\
\hline
\end{tabular}

Source: own work.

\subsection{Outlier Analysis of EA Region}

Table 5 summarizes the yearly outlier frequencies of both imports and exports between Poland and EA countries from 1999 to 2013. The big outliers manifested in Poland's accession to the EU in 2004, the global financial crisis in 2008 and 2009, and the subsequent European debt crisis from 2010 to 2013 . Thus, the macro analysis was divided into five periods: before Poland's accession to the EU, 1999-2003; Poland's accession to the EU, 2004; before the global financial crisis, 2005-2007; the global financial crisis, 2008-2009; and the European debt crisis, 2010-2013.

Table 5. Yearly outlier frequencies of Poland's imports and exports with EA region from 1999 to 2013

\begin{tabular}{|c|c|c|c|c|c|c|c|c|c|c|c|c|c|}
\hline \multirow{3}{*}{$\begin{array}{r}\text { Term; } \\
\text { year }\end{array}$} & \multicolumn{6}{|c|}{ Effect $(+)$} & \multicolumn{6}{|c|}{ Effect (-) } & \multirow{3}{*}{ Total } \\
\hline & \multicolumn{5}{|c|}{ outlier types } & \multirow{2}{*}{ subtotal } & \multicolumn{5}{|c|}{ outlier types } & \multirow{2}{*}{ subtotal } & \\
\hline & $\mathrm{AO}$ & AOT12 & LS & LST12 & $\mathrm{T} 12$ & & $\mathrm{AO}$ & AOT12 & LS & LST12 & $\mathrm{T} 12$ & & \\
\hline 1 & 2 & 3 & 4 & 5 & 6 & 7 & 8 & 9 & 10 & 11 & 12 & 13 & 14 \\
\hline Import & 56 & 2 & 20 & 2 & 7 & 87 & 21 & 1 & 26 & 5 & 8 & 61 & 148 \\
\hline 1999 & & & 2 & & & 2 & & & & & & & 2 \\
\hline 2000 & & & & & & & 2 & & 1 & & & 3 & 3 \\
\hline 2001 & 1 & & & & & 1 & 1 & & 1 & & & 2 & 3 \\
\hline 2002 & 2 & 1 & & & & 3 & & & 1 & & & 1 & 4 \\
\hline 2003 & 1 & & 1 & & 2 & 4 & & & & & 1 & 1 & 5 \\
\hline 2004 & 5 & & & & & 5 & 1 & & 3 & 4 & 2 & 10 & 15 \\
\hline 2005 & 3 & & 1 & & 1 & 5 & & & & & 1 & 1 & 6 \\
\hline 2006 & 4 & & 1 & & & 5 & & & & & 1 & 1 & 6 \\
\hline 2007 & 4 & 1 & 1 & & & 6 & & & 1 & & & 1 & 7 \\
\hline 2008 & 6 & & 2 & 1 & & 9 & 5 & & 2 & & & 7 & 16 \\
\hline
\end{tabular}




\begin{tabular}{|l|c|c|c|c|c|c|c|c|c|c|c|c|c|}
\hline 1 & 2 & 3 & 4 & 5 & 6 & 7 & 8 & 9 & 10 & 11 & 12 & 13 & 14 \\
\hline 2009 & 2 & & 4 & & 2 & 8 & 1 & & 4 & & 2 & 7 & 15 \\
\hline 2010 & 10 & & 3 & & 1 & 14 & & & 1 & 1 & & 2 & 16 \\
\hline 2011 & 2 & & 3 & 1 & 1 & 7 & 4 & & 4 & & 1 & 9 & 16 \\
\hline 2012 & 8 & & & & & 8 & 3 & 1 & 6 & & & 10 & 18 \\
\hline 2013 & 8 & & 2 & & & 10 & 4 & & 2 & & & 6 & 16 \\
\hline Export & 108 & 3 & 24 & 1 & 4 & 140 & 21 & & 10 & & 4 & 35 & 175 \\
\hline 1999 & 4 & & 1 & & 1 & 6 & 1 & & & & & 1 & 7 \\
\hline 2000 & 5 & & 2 & & & 7 & 1 & & & & & 1 & 8 \\
\hline 2001 & 3 & & & & 1 & 4 & 2 & & 1 & & 1 & 4 & 8 \\
\hline 2002 & 6 & & & & & 6 & & & 1 & & & 1 & 7 \\
\hline 2003 & 6 & & 1 & & & 7 & & & & & & & 7 \\
\hline 2004 & 13 & 1 & 2 & & & 16 & 1 & & & & & 1 & 17 \\
\hline 2005 & 5 & & 1 & & & 6 & 1 & & & & & 1 & 7 \\
\hline 2006 & 6 & & 1 & & & 7 & 1 & & 1 & & & 2 & 9 \\
\hline 2007 & 7 & & 1 & & & 8 & & & & & & & 8 \\
\hline 2008 & 7 & & 2 & & & 9 & 1 & & 5 & & 1 & 7 & 16 \\
\hline 2009 & 7 & & 3 & & & 10 & 3 & & & & 1 & 4 & 14 \\
\hline 2010 & 10 & & 1 & & & 11 & 1 & & & & & 1 & 12 \\
\hline 2011 & 4 & 2 & 5 & 1 & 2 & 14 & 3 & & & & & 3 & 17 \\
\hline 2012 & 10 & & 3 & & & 13 & 5 & & 1 & & 1 & 7 & 20 \\
\hline 2013 & 15 & & 1 & & & 16 & 1 & & 1 & & & 2 & 18 \\
\hline Total & 164 & 5 & 44 & 3 & 11 & 227 & 42 & 1 & 36 & 5 & 12 & 96 & 323 \\
\hline
\end{tabular}

Source: own work.

Overall, the results showed a strong contrast in outliers between imports and exports. In the 1999-2013 period, there were $140(80 \%)$ positive outliers of 175 in exports and 87 (59\%) of 148 in imports. Moreover, the permanent effects (LSs and LST12s) of the negative outliers in imports appeared more frequently than in exports, at $51 \%$ and $29 \%$ of the total, respectively. Generally, the path of exports was more unstable than that of imports but was potentially aggressive in this study period.

In the 1999-2003 period, before Poland's accession to the EU, the outliers of exports were more frequent than those of imports, at 37 and 17, respectively, compared with the other study periods. The frequent AOs and AOT12s of exports also indicated a somewhat trial-and-error marketing approach, resulting in $76 \%$ of the total in this period, while those of imports were only $47 \%$. Conversely, the negative effects of imports were $41 \%$ of the total, while those of exports were only $19 \%$. Based on the results, the outliers that were detected predicted a probable decline in imports and a potential increase in exports.

The foreknowledge of Poland's accession to the EU in 2004 marked a critical watershed in trade flows between Poland and EA. As expected, the 2004 outliers of both imports and exports were more frequent than in the previous years. The total number of outliers in 2004 immediately 
increased to 32 from 9 to 12 in the 1999-2003 period. The outliers of both imports and exports were almost equal at 15 and 17, respectively. Notably, the outliers of imports quickly responded to this expected event in April and May of 2004 at around 11 (73\%) of 15, but those of exports from August to December were 11 (65\%) of 17 (Table 6). Regarding the effects of outliers, there was only one negative outlier of exports, while those of imports were $10(67 \%)$, with nearly permanent effects, three LSs, four LST12s, and two T12s. These fit Kawecka-Wyrzykowska's (2003) evaluation of the adoption of EU membership in trade, which found changes in Polish import rules, rather than in export rules, particularly for non-EU countries. This result is consistent with the statistics on trade between Poland and EA, which indicated a steep decrease in imports and a large increase in exports in 2004 (Table 2).

Table 6. Monthly outlier frequencies of Poland's imports and exports with EA region in 2004

\begin{tabular}{|c|c|c|c|c|c|c|c|c|c|c|}
\hline \multirow{3}{*}{$\begin{array}{c}\text { Term; } \\
\text { year/month }\end{array}$} & \multicolumn{4}{|c|}{ Effect $(+)$} & \multicolumn{5}{|c|}{ Effect $(-)$} & \multirow{3}{*}{ Total } \\
\hline & \multicolumn{3}{|c|}{ outlier types } & \multirow{2}{*}{ subtotal } & \multicolumn{4}{|c|}{ outlier types } & \multirow{2}{*}{ subtotal } & \\
\hline & $\mathrm{AO}$ & AOT12 & LS & & $\mathrm{AO}$ & LS & LST12 & $\mathrm{T} 12$ & & \\
\hline Import & 5 & & & 5 & 1 & 3 & 4 & 2 & 10 & 15 \\
\hline $2004 / 04$ & 3 & & & 3 & & & & & & 3 \\
\hline $2004 / 05$ & & & & & 1 & 2 & 4 & 1 & 8 & 8 \\
\hline $2004 / 08$ & 1 & & & 1 & & & & & & 1 \\
\hline $2004 / 10$ & 1 & & & 1 & & 1 & & & 1 & 2 \\
\hline $2004 / 11$ & & & & & & & & 1 & 1 & 1 \\
\hline Export & 13 & 1 & 2 & 16 & 1 & & & & 1 & 17 \\
\hline $2004 / 01$ & 1 & & & 1 & 1 & & & & 1 & 2 \\
\hline $2004 / 04$ & 1 & & & 1 & & & & & & 1 \\
\hline $2004 / 05$ & & & 1 & 1 & & & & & & 1 \\
\hline $2004 / 06$ & 1 & & 1 & 2 & & & & & & 2 \\
\hline $2004 / 08$ & 2 & 1 & & 3 & & & & & & 3 \\
\hline $2004 / 09$ & 2 & & & 2 & & & & & & 2 \\
\hline $2004 / 10$ & 2 & & & 2 & & & & & & 2 \\
\hline $2004 / 11$ & 2 & & & 2 & & & & & & 2 \\
\hline $2004 / 12$ & 2 & & & 2 & & & & & & 2 \\
\hline Total & 18 & 1 & 2 & 21 & 2 & 3 & 4 & 2 & 11 & 32 \\
\hline
\end{tabular}

Source: own work.

In the 2005-2007 period, the yearly performance of both import and export outliers returned to moderate, between six and nine (Table 5). Under the burgeoning economy, almost all outliers of both imports and exports were positive, at $84 \%$ and $88 \%$ of the totals, respectively. The patterns of outlier types in imports and exports were homogeneous, compared with the other periods. These results confirmed both Poland's strong domestic demands and enhanced export competitiveness through EU membership and FDI. Ando and Kimura (2013) found that 
the connection between Poland and EA developed significantly in the 2000s, particularly after the former's accession to the EU. As a result of the reduction in the transition costs of global trade, a production linkage between Europe and Asia via Poland is highly possible.

However, the shock of the global financial crisis in 2008 and 2009 caused turbulence in trade between Poland and EA. The number of outliers increased to 32 in 2008 and 29 in 2009 , compared to 13 and 15 in the 2005-2007 period. The positive outliers remained significant during this crisis, at $63 \%$ of exports and $55 \%$ of imports. The permanent effects were dominant over the previous years, at around 37\% of outliers in both 2008 and 2009. There were seven positive LSs and four negative LSs in 2009, despite four positive LSs, one positive LST12, and seven negative LSs in 2008. It is possible that this sudden crisis introduced another trade path between Poland and EA. Like the trade statistics show in Table 1, since 2009, EA's share of Poland's imports has returned to the country's pre-EU accession level, and that of exports has increased to a new high.

The subsequent European debt crisis in the 2010-2013 period instantly resulted in unprecedented outliers: 33 in 2011, 38 in 2012, and 34 in 2013. Interestingly, the majority of outlier effects in this period were positive, particularly in exports by $81 \%$. In addition, regarding the types of outliers, the outliers of exports were more aggressive than those of imports. Exports showed 10 positive LSs, one positive LST12, and two negative LSs and LST12s, while imports showed eight positive LSs and one positive LST12, but 14 negative LSs. The results indicated a severe decline in Polish domestic demands and a serious search for extra-EU export markets.

\subsection{Outlier Analysis of EA Countries}

China is widely regarded as a giant export machine in world trade. The continuous increase in Poland's imports from China translated into the fewest outliers among EA countries over this study period. The outliers of imports did not appear until 2004: one AO and one T12 (Table 7) because of the trade adjustment caused by Poland's accession to the EU. The next outlier showed in 2008 by one AO, again because of the global financial crisis. With few outliers, the imports increased steadily before the crisis. However, the negative outliers of imports with permanent effects have emerged since 2009, which might be a sign of slowing growth despite the still-new high volume year by year. Regarding exports, the total number of outliers is much greater than for imports in this study period, at 23 and seven, respectively. In addition, the outliers of exports were dominated by positive effects at $83 \%$ of the total. Trial-and-error export marketing was evidenced by the frequent number of AOs at $87 \%$ of total export outliers, of which $65 \%$ were clustered in the 2008-2013 period. This result indicates that Poland struggled to maintain its 
exports to China against the augmenting imports. However, the increase in potential exports evidenced by these results corroborated Palonka's (2010) optimistic view.

Table 7. Period outlier frequencies of Poland's imports and exports with EA countries from 1999 to 2013

\begin{tabular}{|c|c|c|c|c|c|c|c|c|c|c|c|c|}
\hline Effects; types & $\mathrm{CN}$ & $\mathrm{HK}$ & ID & JP & KR & MY & PH & SG & $\mathrm{TH}$ & TW & $\mathrm{VN}$ & Total \\
\hline 1 & 2 & 3 & 4 & 5 & 6 & 7 & 8 & 9 & 10 & 11 & 12 & 13 \\
\hline Import & 7 & 13 & 18 & 10 & 21 & 10 & 14 & 10 & 16 & 9 & 20 & 148 \\
\hline 1999-2003 & & 1 & 1 & 1 & 3 & 1 & 7 & & & 1 & 2 & 17 \\
\hline+ & & 1 & & & 1 & 1 & 5 & & & 1 & 1 & 10 \\
\hline $\mathrm{AO}$ & & 1 & & & & & 3 & & & & & 4 \\
\hline AOT12 & & & & & & & 1 & & & & & 1 \\
\hline LS & & & & & 1 & 1 & & & & & 1 & 3 \\
\hline T12 & & & & & & & 1 & & & 1 & & 2 \\
\hline- & & & 1 & 1 & 2 & & 2 & & & & 1 & 7 \\
\hline $\mathrm{AO}$ & & & & & 1 & & 2 & & & & & 3 \\
\hline LS & & & 1 & 1 & 1 & & & & & & & 3 \\
\hline $\mathrm{T} 12$ & & & & & & & & & & & 1 & 1 \\
\hline 2004-2004 & 2 & & 2 & 1 & 1 & 1 & 2 & 1 & 2 & 1 & 2 & 15 \\
\hline+ & 1 & & 1 & & & & 1 & & 1 & & 1 & 5 \\
\hline $\mathrm{AO}$ & 1 & & 1 & & & & 1 & & 1 & & 1 & 5 \\
\hline- & 1 & & 1 & 1 & 1 & 1 & 1 & 1 & 1 & 1 & 1 & 10 \\
\hline $\mathrm{AO}$ & & & & & 1 & & & & & & & 1 \\
\hline LS & & & & & & & 1 & 1 & & 1 & & 3 \\
\hline LST12 & & & 1 & 1 & & 1 & & & 1 & & & 4 \\
\hline T12 & 1 & & & & & & & & & & 1 & 2 \\
\hline $2005-2007$ & & 2 & 1 & 3 & 5 & 5 & & & 1 & 2 & & 19 \\
\hline+ & & 2 & & 3 & 5 & 4 & & & 1 & 1 & & 16 \\
\hline $\mathrm{AO}$ & & 1 & & 2 & 3 & 3 & & & 1 & 1 & & 11 \\
\hline AOT12 & & 1 & & & & & & & & & & 1 \\
\hline LS & & & & 1 & 2 & & & & & & & 3 \\
\hline $\mathrm{T} 12$ & & & & & & 1 & & & & & & 1 \\
\hline- & & & 1 & & & 1 & & & & 1 & & 3 \\
\hline LS & & & 1 & & & & & & & & & 1 \\
\hline $\mathrm{T} 12$ & & & & & & 1 & & & & 1 & & 2 \\
\hline 2008-2009 & 3 & 2 & 6 & 2 & 5 & 1 & 2 & 1 & 3 & 3 & 3 & 31 \\
\hline+ & 1 & 2 & 3 & & 2 & 1 & 1 & 1 & 2 & 2 & 2 & 17 \\
\hline $\mathrm{AO}$ & 1 & 2 & 2 & & & 1 & & & 1 & & 1 & 8 \\
\hline LS & & & 1 & & 1 & & 1 & & 1 & 1 & 1 & 6 \\
\hline LST12 & & & & & 1 & & & & & & & 1 \\
\hline T12 & & & & & & & & 1 & & 1 & & 2 \\
\hline+ & 2 & & 3 & 2 & 3 & & 1 & & 1 & 1 & 1 & 14 \\
\hline $\mathrm{AO}$ & & & 1 & 1 & 1 & & 1 & & & 1 & 1 & 6 \\
\hline LS & 1 & & 1 & 1 & 2 & & & & 1 & & & 6 \\
\hline T12 & 1 & & 1 & & & & & & & & & 2 \\
\hline
\end{tabular}




\begin{tabular}{|c|c|c|c|c|c|c|c|c|c|c|c|c|}
\hline 1 & 2 & 3 & 4 & 5 & 6 & 7 & 8 & 9 & 10 & 11 & 12 & 13 \\
\hline 2010-2013 & 2 & 8 & 8 & 3 & 7 & 2 & 3 & 8 & 10 & 2 & 13 & 66 \\
\hline+ & & 7 & 3 & 2 & 3 & 2 & 2 & 8 & 3 & 1 & 8 & 39 \\
\hline $\mathrm{AO}$ & & 6 & 1 & 2 & 1 & 1 & 2 & 8 & 3 & & 4 & 28 \\
\hline LS & & 1 & 1 & & 2 & 1 & & & & 1 & 2 & 8 \\
\hline LST12 & & & 1 & & & & & & & & & 1 \\
\hline T12 & & & & & & & & & & & 2 & 2 \\
\hline- & 2 & 1 & 5 & 1 & 4 & & 1 & & 7 & 1 & 5 & 27 \\
\hline $\mathrm{AO}$ & & & 1 & & 2 & & & & 6 & 1 & 1 & 11 \\
\hline AOT12 & & & 1 & & & & & & & & & 1 \\
\hline LS & 2 & 1 & 3 & 1 & 1 & & 1 & & 1 & & 3 & 13 \\
\hline LST12 & & & & & 1 & & & & & & & 1 \\
\hline T12 & & & & & & & & & & & 1 & 1 \\
\hline Export & 23 & 27 & 25 & 12 & 19 & 7 & 6 & 15 & 11 & 15 & 15 & 175 \\
\hline 1999-2003 & 2 & 3 & 13 & 7 & 2 & & & 4 & 1 & 2 & 3 & 37 \\
\hline+ & 2 & 2 & 10 & 5 & 2 & & & 4 & 1 & 2 & 2 & 30 \\
\hline $\mathrm{AO}$ & 2 & 1 & 8 & 2 & 2 & & & 4 & 1 & 2 & 2 & 24 \\
\hline LS & & 1 & 1 & 2 & & & & & & & & 4 \\
\hline T12 & & & 1 & 1 & & & & & & & & 2 \\
\hline- & & 1 & 3 & 2 & & & & & & & 1 & 7 \\
\hline $\mathrm{AO}$ & & & 3 & 1 & & & & & & & & 4 \\
\hline LS & & 1 & & & & & & & & & 1 & 2 \\
\hline T12 & & & & 1 & & & & & & & & 1 \\
\hline 2004-2004 & 3 & 1 & 4 & 1 & & & 1 & & 2 & 2 & 3 & 17 \\
\hline+ & 3 & 1 & 4 & & & & 1 & & 2 & 2 & 3 & 16 \\
\hline $\mathrm{AO}$ & 3 & 1 & 3 & & & & 1 & & & 2 & 3 & 13 \\
\hline AOT12 & & & & & & & & & 1 & & & 1 \\
\hline LS & & & 1 & & & & & & 1 & & & 2 \\
\hline- & & & & 1 & & & & & & & & 1 \\
\hline $\mathrm{AO}$ & & & & 1 & & & & & & & & 1 \\
\hline $2005-2007$ & 3 & 4 & 4 & & 2 & 2 & 1 & 1 & 2 & 2 & 3 & 24 \\
\hline+ & 2 & 4 & 2 & & 2 & 2 & 1 & 1 & 2 & 2 & 3 & 21 \\
\hline $\mathrm{AO}$ & 1 & 4 & 2 & & 1 & 2 & 1 & 1 & 2 & 1 & 3 & 18 \\
\hline LS & 1 & & & & 1 & & & & & 1 & & 3 \\
\hline- & 1 & & 2 & & & & & & & & & 3 \\
\hline $\mathrm{AO}$ & 1 & & 1 & & & & & & & & & 2 \\
\hline LS & & & 1 & & & & & & & & & 1 \\
\hline $2008-2009$ & 5 & 2 & 4 & 3 & 4 & 2 & & & 4 & 3 & 3 & 30 \\
\hline+ & 3 & 2 & 3 & 1 & 1 & 2 & & & 3 & 2 & 2 & 19 \\
\hline $\mathrm{AO}$ & 3 & 2 & 2 & & 1 & 2 & & & 2 & 1 & 1 & 14 \\
\hline LS & & & 1 & 1 & & & & & 1 & 1 & 1 & 5 \\
\hline- & 2 & & 1 & 2 & 3 & & & & 1 & 1 & 1 & 11 \\
\hline $\mathrm{AO}$ & 2 & & 1 & & 1 & & & & & & & 4 \\
\hline LS & & & & 1 & 2 & & & & & 1 & 1 & 5 \\
\hline $\mathrm{T} 12$ & & & & 1 & & & & & 1 & & & 2 \\
\hline 2010-2013 & 10 & 17 & & 1 & 11 & 3 & 4 & 10 & 2 & 6 & 3 & 67 \\
\hline+ & 9 & 14 & & & 6 & 3 & 3 & 10 & 2 & 5 & 2 & 54 \\
\hline $\mathrm{AO}$ & 7 & 12 & & & 2 & 3 & 2 & 9 & 1 & 2 & 1 & 39 \\
\hline AOT12 & & & & & 1 & & 1 & & & & & 2 \\
\hline
\end{tabular}




\begin{tabular}{|l|c|c|c|c|c|c|c|c|c|c|c|c|}
\hline & 2 & 3 & 4 & 5 & 6 & 7 & 8 & 9 & 10 & 11 & 12 & 13 \\
\hline LS & 2 & 2 & & & 3 & & & 1 & 1 & 1 & & 10 \\
\hline LST12 & & & & & & & & & & & 1 & 1 \\
\hline T12 & & & & & & & & & & 2 & & 2 \\
\hline- & 1 & 3 & & 1 & 5 & & 1 & & & 1 & 1 & 13 \\
\hline AO & & 3 & & 1 & 5 & & & & & & & 10 \\
\hline LS & & & & & & & & & & 1 & 1 & 2 \\
\hline T12 & 30 & 40 & 43 & 22 & 40 & 17 & 20 & 25 & 27 & 24 & 35 & 323 \\
\hline Total & & & & & & & & & \\
\hline
\end{tabular}

Source: own work.

Hong Kong is an extremely flexible and efficient service economy, according to the ETI reports (Hanouz et al., 2014; Lawrence et al., 2010). However, the manufacturing sector has dwindled because of the rise of China. Consequentially, the import/export ratio of Poland to Hong Kong decreased from 1.36 in 1999 to 0.34 in 2013. In particular, since 2004, the ratio has not exceeded 1.0, which indicates that Poland's exports to Hong Kong are much greater than its imports from Hong Kong, which has never been the case among EA countries. In this study, the most frequent outlier of exports was in relation to Hong Kong. It amounted to 27 outliers in the 1999-2013 period, 17 (63\%) of which showed during the European debt crisis when Poland seriously reoriented its export geography to outside the EU. Regarding relatively insignificant imports, only three outliers appeared before the global financial crisis, but 10 (77\%) outliers were clustered in the 2008-2013 period. This result indicates that the role of Hong Kong in Poland's trade is an adjustable marketing point in Asia, especially for exports.

Singapore, like Hong Kong, was ranked the first ETI in the world since 2010 (Hanouz et al., 2014; Lawrence et al., 2010). All outliers were positive, except one negative in imports in 2004. The outliers of imports were uniquely clustered during the period of the European debt crisis: 8 of 10. The clustering outliers of exports appeared before Poland's accession to the EU, with four AOs. They appeared strong during the European debt crisis, with nine AOs and one LS. Significantly, the European debt crisis brought new opportunities for both imports and exports between Poland and Singapore.

Although Japan has one of the world's top five trading volumes, it has not developed significant trade with Poland. This study found few outliers of both imports and exports at 10 and 12, respectively. The outliers of imports emerged positively after Poland's accession to the EU, with two AOs and one LS in the 2005-2007 period, compared with only one negative LS in the 1999-2003 period. The crises, however, resulted in two negative LSs that corresponded to the fluctuating values, which suggested sluggish imports. By contrast, outliers of exports were clustered in the 1999-2003 period, at 7 (60\%) of 12, with almost positive effects. There 
was only one outlier during the European debt crisis, which corresponded to robust growth and suggested increasing exports.

South Korea, as Poland's top FDI position in Asia, generates significant trade with Poland. The number of outliers of both imports and exports was considerable and parallel, compared with the other countries at 21 and 19, respectively. In addition, the LSs occurred most frequently among the countries considered in this study, at 18 (45\%) of 40. In the 2005-2007 period, all outliers were positive in response to Poland's accession to the EU. During the European debt crisis, however, imports showed mixed positive and negative effects without a discernible overall trend. During the same period, exports showed three positive LSs, despite five negative AOs, suggesting a slight increase.

Taiwan's trade with Poland has been depressed for several years, partly because China has absorbed large trade opportunities. The outliers of imports numbered nine, with only one in the 1999-2003 period. Although the two positive LSs rarely showed during the crises, the changing volumes of imports were unfavorable. Relatively, exports presented a dynamic track, with 15 outliers: eight AOs, five LSs, and two T12s. The clustering outliers of exports appeared during the crises, but the mixed positive and negative effects showed in LSs, suggesting a doubtful progress.

Malaysia has developed balanced trade with Poland. Outliers of exports were evident after the EU accession, with all positive AOs. This result indicated that Poland attempted to broaden this market, which corresponded to the steady growth in volume. Comparatively, there was only one outlier of imports in the 1999-2003 period: a positive LS, suggesting a growth phase. However, Poland's accession to the EU resulted in a slump in imports. During the crises, the few outliers of imports indicated a new perspective, corresponding to the slow increase in volumes back to the 1999-2003 levels.

Thailand's trade with Poland peaked substantially during the European debt crisis. The outliers of imports were inactive before the crises. The outliers of imports were clustered in the European debt crisis, at $10(63 \%)$ of 16 . However, there were one negative LS and six negative AOs, which indicated unstable growth. In contrast, there were only 11 outliers of exports, with only one negative effect. These outliers appeared during the European debt crisis; one AO and one LS had positive effects. This result corresponds to obviously robust growth, suggesting a motivational force in exports.

Among the countries that were studied, Indonesia showed the greatest number of outliers, as well as appreciably divergent paths between imports and exports. The outliers of imports were significantly clustered during the crises, at 14 (78\%) of 18 , while the outliers of exports were 
13 (52\%) of 25 during the 1999-2003 period. During the European debt crisis, negative effects prevailed in imports, with three LSs, one AO, and one AOT12. During the same period, there was no outlier of exports but corresponded to the increasing volumes. These results suggested that Poland's exports to Indonesia are greater than its imports from that country.

Vietnam is a budding market economy and benefits from the EU Generalized Scheme of Preferences in trade. Clustering outliers of imports significantly appeared during the European debt crisis, at 13 (65\%) of 20. However, the mixed permanent effects - two positive and three negative LSs - suggested an unstable increase in imports. Regarding exports, there were no markedly clustering outliers, and similar to imports, mixed permanent effects showed during the 2008-2013 period. Although Vietnam enjoys a trade preference with the EU, its trade relations with Poland remain weak.

The Philippines' trade with Poland remains small primarily because of its low volumes in world trade (seen in Appendix). Clustering outliers of imports appeared in the 1999-2003 period, at 7 of 14. During the crises, although volumes returned to the levels of the 1999-2003 period, the few outliers with mixed effects suggested a cool and distant relationship. Exports were negligible before the crises, at a yearly average of only $€ 7$ million in the 1999-2007 period. The clustering outliers of exports showed during the European debt crisis, at four (67\%) of six. However, there were no permanent effects of LSs, and the volumes were rather low, suggesting reduced motivation.

Table 8. Summary of period outliers of Poland's imports and exports with EA countries from 1999 to 2013

\begin{tabular}{|c|c|c|c|c|c|c|c|c|c|c|c|}
\hline & $\mathrm{CN}$ & $\mathrm{HK}$ & ID & JP & $\mathrm{KR}$ & MY & $\mathrm{PH}$ & $\mathrm{SG}$ & $\mathrm{TH}$ & TW & $\mathrm{VN}$ \\
\hline \multicolumn{12}{|l|}{ Import } \\
\hline 1999-2003 & $\mathrm{N}$ & & & & & & $\mathrm{C}$ & $\mathrm{N}$ & $\mathrm{N}$ & & \\
\hline 2004-2004 & & $\mathrm{N}$ & & & & & & & & & \\
\hline $2005-2007$ & $\mathrm{~N}$ & & & $\mathrm{C}$ & & $\mathrm{C}$ & $\mathrm{N}$ & $\mathrm{N}$ & & & $\mathrm{N}$ \\
\hline $2008-2009$ & $\mathrm{C}$ & & & & & & & & & $\mathrm{C}$ & \\
\hline $2010-2013$ & & $\mathrm{C}$ & $\mathrm{C}$ & $\mathrm{C}$ & $\mathrm{C}$ & & & $\mathrm{C}$ & $\mathrm{C}$ & & $\mathrm{C}$ \\
\hline \multicolumn{12}{|l|}{ Export } \\
\hline 1999-2003 & & & $\mathrm{C}$ & $\mathrm{C}$ & & $\mathrm{N}$ & $\mathrm{N}$ & & & & \\
\hline 2004-2004 & & & & & $\mathrm{N}$ & $\mathrm{N}$ & & $\mathrm{N}$ & & & \\
\hline $2005-2007$ & & & & $\mathrm{~N}$ & & & & & & & \\
\hline 2008-2009 & & & & & & & $\mathrm{N}$ & $\mathrm{N}$ & $\mathrm{C}$ & & \\
\hline 2010-2013 & $\mathrm{C}$ & $\mathrm{C}$ & $\mathrm{N}$ & & $\mathrm{C}$ & $\mathrm{C}$ & $\mathrm{C}$ & $\mathrm{C}$ & & $\mathrm{C}$ & \\
\hline
\end{tabular}

Notes: $C$ as clustering outliers; $N$ as no outliers.

Source: own work. 
The outlier spectrum summarized in Table 8 shows the most significantly clustering outliers $(\mathrm{C})$ and no outliers $(\mathrm{N})$ for a given series in the five periods. The clustering formation was inevitable, with the exception of exports to Vietnam, and intensive during the crises. Not all events disturbed the trade paths of every country. For instance, Poland's accession to the EU did not cause outliers in imports from Hong Kong or in exports to South Korea, Malaysia, and Singapore. No outliers were shown in exports to the Philippines and Singapore during the global financial crisis or in exports to Indonesia during the European debt crisis. These empirical results support the position that trade factors are complicated and that a diversified business strategy is necessary.

\section{Conclusions}

The dramatic trade path between Poland and EA was described from a macro perspective, from depending through distancing and then improving to a chance of approaching. The results of this outlier analysis demonstrated that bilateral trade was closely related to the following remarkable events: Poland's accession to the EU in 2004, the global financial crisis in 2008 and 2009, and the European debt crisis from 2010 to 2013. These crises accidentally created a greater increase in trade between Poland and EA than EU membership did, particularly in regard to exports.

The results of the outlier analyses, especially clustering, showed the different paths of bilateral trade between Poland and each EA country. Despite the crises, there was a significant increase in Poland's exports to China, Hong Kong, Japan, South Korea, Malaysia, Singapore, and Thailand. Increases in Poland's exports to EA also showed in Indonesia and Taiwan, while no increase was evident in exports to Vietnam and the Philippines. In contrast, with the exception of those from China, Poland's imports generally showed some stagnation. The European debt crisis negatively affected imports from Hong Kong, South Korea, Malaysia, Singapore, Thailand, and Vietnam, notwithstanding the unclear trends.

The results of the study indicate that Poland should stimulate bilateral trade with EA when economic recovery in the EU remains slow. Regarding business practice, a survey of the economic climate showed that Polish entrepreneurs are willing to extend to new foreign markets (National Bank of Poland, 2013). As an extra-EU market, the sophisticated EA surpasses the CIS in enabling trade. Furthermore, because of the "entrepreneurial DNA" of Poles (Kowalewski, Rybinski, 2011), the risk of geographical distance between Poland and EA could be reduced. For Poland, the other advantage of developing a heterogeneous EA market, 
according to Parteka's (2013) econometric results, is its high degree of trade diversification, both in terms of products and partners, compared with 163 countries worldwide. In the near future, Poland's accession to the eurozone will also greatly reduce transaction costs and consolidate the international competitiveness of Polish companies (Dzikowska et al., 2014).

Poland has made efforts to foster trade with China (Palonka, 2010). However, Fürst and Pleschová (2010) investigated the Czech and Slovak cases of trade relations with China and found that the expected reductions in trade deficits through gaining China's favor were not forthcoming. In the case of Poland, the trade deficit with China tends to multiply year by year, increasing to $€ 6.9$ billion in 2013. Based on the results of this study, Poland should maintain and boost bilateral trade with other EA countries to spread the risk throughout the EA region.

Appendix. Key indicators of studied countries

\begin{tabular}{|l|r|r|c|c|c|c|}
\hline Country name & $\begin{array}{c}\text { Area } \\
\text { (sq. km) }\end{array}$ & $\begin{array}{c}\text { Population } \\
\text { (thou.) }\end{array}$ & $\begin{array}{c}\text { GDP (current, } \\
\text { bil. US\$)** }\end{array}$ & $\begin{array}{c}\text { GDP per capital } \\
\text { (PPP, US\$)** }\end{array}$ & $\begin{array}{c}\text { Import } \\
\text { (bil. US\$)** }\end{array}$ & $\begin{array}{c}\text { Export } \\
\text { (bil. US\$)** }\end{array}$ \\
\hline Poland & 312,685 & 38,346 & 514 & 21,100 & 207 & 202 \\
\hline China & $9,596,960$ & $1,355,693$ & 9,330 & 9,800 & 1,950 & 2,210 \\
\hline Hong Kong & 1,104 & 7,113 & 272 & 52,700 & 521 & 456 \\
\hline Indonesia & $1,904,569$ & 253,610 & 868 & 5,200 & 179 & 179 \\
\hline Japan & 377,915 & 127,103 & 5,007 & 37,100 & 767 & 697 \\
\hline South Korea & 99,720 & 49,040 & 1,198 & 33,200 & 517 & 557 \\
\hline Malaysia & 329,847 & 30,073 & 312 & 17,500 & 193 & 231 \\
\hline Philippines & 300,000 & 107,668 & 272 & 4,700 & 64 & 47 \\
\hline Singapore & 697 & 5,567 & 296 & 62,400 & 373 & 410 \\
\hline Taiwan & 35,980 & 23,360 & 485 & 39,600 & 269 & 306 \\
\hline Thailand & 513,120 & 67,741 & 401 & 9,900 & 219 & 225 \\
\hline Vietnam & 331,210 & 93,422 & 170 & 4,000 & 121 & 129 \\
\hline
\end{tabular}

Notes: * July-2014 estimates; ** 2013 estimates.

Source: The World Factbook, Central Intelligence Agency (CIA), retrieved on October 10, 2014, from https://www.cia. gov/library/publications/the-world-factbook.

\section{References}

Acharya, A. (2010). Asia is not one. The Journal of Asian Studies, 69 (04), 1001-1013. DOI: $10.1017 / \mathrm{S} 0021911810002871$.

Ando, M., Kimura, F. (2013). Production linkage of Asia and Europe via Central and Eastern Europe. Journal of Economic Integration, 28, 204-240. DOI: 10.11130/jei.2013.28.2.204. 
Balke, N.S., Fomby, B.T. (1994). Large shocks, small shocks, and economic fluctuations: Outliers in macroeconomic time series. Journal of Applied Econometrics, 9 (2), 181-200. DOI: 10.1002/jae.3950090205.

Barnett, V., Lewis, T. (1994). Outliers in statistical data (3 ${ }^{\text {rd }}$ ed.). New York: Wiley.

Belka, M. (2013). How Poland's EU membership helped transform its economy (Occasional Paper no. 88). Retrieved from Group of Thirty website: http://group30.org/images/PDF/ OP88.pdf.

Biswas, R. (2013). Future Asia: The new gold rush in the East. Hampshire, England: Palgrave Macmillan.

Duszczyk, M. (2014). Poland under economic crisis conditions. Perspectives on European Politics and Society, 15 (3), 370-384. DOI: 10.1080/15705854.2014.912404.

Dzikowska, M., Gorynia, M., Jankowska, B., Pietrzykowski, M. (2014). International competitiveness of Polish companies and the perspective of Poland joining the Euro Zone. Society and Economy, 36 (1), 95-117. DOI: 10.1556/SocEc.36.2014.1.6.

Farley, E.V. Jr., Murphy, J.M. (1997). Time series outlier analysis: Evidence for management and environmental influences on Sockeye salmon catches in Alaska and Northern British Columbia. Alaska Fishery Research Bulletin, 4 (1), 36-53. DOI: 10.1080/09668136.201 0.504387 .

Fürst, R., Pleschová, G. (2010). Czech and Slovak relations with China: Contenders for China's favour. Europe-Asia Studies, 62 (8), 1363-1381.

Grubbs, F.E. (1969). Procedures for detecting outlying observations in samples. Technometrics, 11 (1), 1-21. DOI: 10.2307/1266761.

Hanouz, M.D., Geiger, T., Doherty, S. (eds.) (2014). The global enabling trade report 2014. Geneva: World Economic Forum.

Hawkins, D.M. (1980). Identification of outliers. London: Chapman and Hall. DOI: 10.1007/97894-015-3994-4.

Hunter, R.J. Jr., Leo, V.R. (2011). Reflections in twenty years of political and economic change in Poland. Global Economy Journal, 11 (1), 1-16. DOI: 10.2202/1524-5861.1727.

Kawecka-Wyrzykowska, E. (2003). The adoption of a common commercial policy towards third countries and joining the community's external economic relations system - Costs and benefits. In: J. Saryusz-Wolski, P. Samecki (eds.), Costs and benefits of Poland's membership in the European Union (pp. 156-167). Warszawa: Centrum Europejskie Natolin.

Kowalewski, O., Rybinski, K. (2011). The hidden transformation: The changing role of the state after the collapse of communism in Central and Eastern Europe. Oxford Review of Economic Policy, 27 (4), 634-657. DOI: 10.1093/oxrep/grr030.

Lawrence, R.Z., Hanouz, D.M., Doherty, S., Moavenzadeh, J. (eds.) (2010). The global enabling trade report 2010. Geneva: World Economic Forum. 
Li, Siu-Hang, Chan, Wai-Sum (2005). Outlier analysis and mortality forecasting: The United Kingdom and Scandinavian Countries. Scandinavian Actuarial Journal, 2005 (3), 187211. DOI: $10.1080 / 03461230510006973$.

Michalski, M.M. (2010). Trade and procurement reform in Poland and China: Responding to the next globalization wave of interdependent economies. Journal of the Washington Institute of China Studies, 5 (2), 96-107.

Nare, H., Maposa, D., Lesaoana, M. (2012). A method for detection and correction of outliers in time series data. African Journal of Business Management, 6 (22), 6631-6639. DOI: $10.5897 / A J B M 12.359$.

National Bank of Poland (2013). Inflation report March 2013. Retrieved from https://www.nbp. pl/en/publikacje/raport_inflacja/iraport_march2013.pdf.

Palonka, K. (2010). Economic and trade relations between Poland and China since 2004. Asia Europe Journal, 8 (3), 369-378. DOI: 10.1007/s10308-010-0284-5.

Parteka, A. (2013). The evolving structure of Polish exports (1994-2010) - Diversification of products and trade partners. Bank $i$ Kredyt, 5, 435-466.

Rae, G. (2013). Avoiding the economic crisis: Pragmatic liberalism and divisions over economic policy in Poland. Europe-Asia Studies, 65 (3), 411-425. DOI: 10.1080/09668136. 2013.779461.

SAS (2002). SAS/ETS® 9 user's guide volumes 1 and 2. North Carolina: SAS Institute.

Tsay, R.S. (1988). Outliers, level shifts, and variance changes in time series. Journal of Forecasting, 7 (1), 1-20. DOI: 10.1002/for.3980070102.

Vintila, D. (2012). Foreign direct investments in Poland: Trend and effects on the economy. Revista Economica, 4-5 (63), 234-251.

Yeung, I., Chiu, N. (2000). An outlier analysis of the Hong Kong stock market index. Applied Economics Letters, 7 (8), 531-534. DOI: 10.1080/13504850050033328. 